\title{
Dietary Supplementation of Nanomaterials in Aquaculture - A Review
}

\author{
Vijayaram Seerengaraj ${ }^{1,2^{*}}$, Yun Zhang Sun ${ }^{1}$, Muthuchamy Maruthupandy ${ }^{3}$, Suruli Kannan ${ }^{2}$, Vasantharaj Seerangaraj ${ }^{4}$ \\ ${ }^{1}$ Fisheries College, Jimei University, Xiamen 361021, China. \\ 2Dept of Environmental Studies, School of Energy Environment and Natural resources, Madurai Kamaraj University, Madurai 625021, \\ Tamil Nadu, India. \\ ${ }^{3}$ Lab of toxicology, Department of Health Sciences, The Graduate School of Dong-A University, 37, Nakdong-daero, 550 Beon-gil, Saha- \\ gu- Busan - 49315, Republic of Korea. \\ ${ }^{4}$ Department of Biotechnology, Hindusthan College of Arts and Science, Coimbatore 641028, Tamil Nadu, India.
}

*Corresponding author's E-mail: vijayarambiotech@gmail.com

Received: 19-07-2021; Revised: 24-09-2021; Accepted: 03-10-2021; Published on: 15-10-2021. ABSTRACT

Aquaculture is the best growing food production division in the globe. Infection outbreaks are also a most important problem for the aquaculture productions. Different types of technological development are uses to improve healthy aquaculture production and enhance the aquatic environment. Nanotechnology is most significant tool for the development of aquatic productions. These techniques are used to detect the infection at short time, deliver the vaccine, drugs and feed for aquatic animals. This review provides information about dietary feed with supplementation of different nanomaterials such as copper, selenium, magnesium, manganese, iron, zinc, chromium, chitosan is utilized to enhance immune system, digestive function, disease resistance, antioxidant activity, growth performance, survival, regulate the metabolic functions, gut health, bio availability, feed intake, feed conversion of diverse aquatic animals. These nanomaterials are mainly focused to improve the nano-nutrient in the feed supplements in aquaculture and enhance the healthy aquatic production.

Keywords: Feed additives, nanomaterials, immune system, fishes, aquaculture.

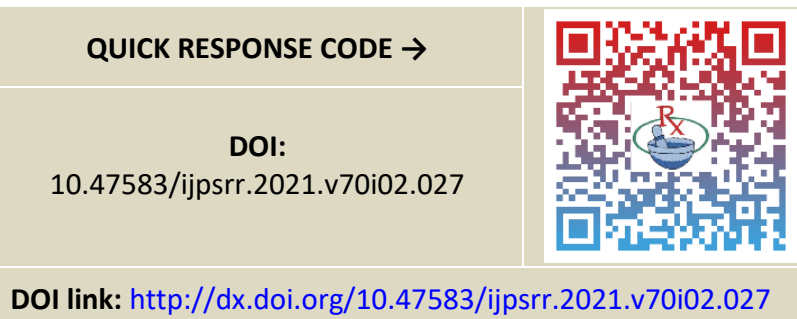

\section{INTRODUCTION}

$\mathrm{n}$ aquaculture industries, nanotechnology might be utilized as a hopeful tool in fast infection detection and delivery of drugs, vaccines, nutrients and hormones cultivable organisms ${ }^{1}$. The main objective for fish industry is to make bigger cost effective fish feed ${ }^{2}$. Fish meal is the vital nutrients for growth element in fish feed. The suitable fish feed ingredients are helpful to enhance for fish growth, disease resistance, immunity and health promoting factors ${ }^{3}$. Minerals are vital nutrients for normal body process as well as requirement differed from depending on fish farms and connections with other elements. Minerals are required lower amounts compared than other nutrients e.g. protein, carbohydrates and fat ${ }^{4}$. They are active in fish contain iron, calcium, zinc, iodine (from marine fish), phosphorus, selenium, fluorine and these elements are tremendously bio available once simply taken through the body. Vitamin B complex is better source for fish species. At same time, liver oil has a vital quantity of fat-soluble vitamins $A, D, E, K$ and vitamin $C^{5}$.
Fish oil is highly rich with polyunsaturated fatty acids particularly omega fatty acids that cannot synthesize by human body ${ }^{5}$.

Feed supplementation has been more familiar administration method in fish cultivating technique and many supplements have been shows that a capable to enhance the fish immune system or regulating the harshness of infections ${ }^{6,7}$. Nanotechnology plays an important role in the future areas of research in animal nutrition ${ }^{8}$. The capability of nanoelements is improve protein stability may effects in number of biological functions such as digestion, metabolism and nutrient uptake ${ }^{9}$. Nowadays nanotechnology received great attention in agriculture and related fields including aquaculture and fisheries. In aquaculture, nanotechnology involves the preparation and utilization of various nanoparticles is very helpful for many ways like, nutrient supplements, therapeutic agents and gene delivery, etc. ${ }^{10}$.

Many investigators reported that dietary feed additives of nanoelements are consuming numerous beneficial effects in nanomaterials such as iron, zinc, selenium, cobalt, etc as well as these elements fulfil the requirement of fish species $^{11,10}$. Chitosan nanoparticles is useful for multiple purposes like controlled release of drugs and gene delivery 107, also feed supplements for obtaining enhanced growth action and meat quality in several fish species Oncorhynchus mykiss ${ }^{12}$, Lates calcarifer ${ }^{111}$, Oreochromis niloticus $^{112}$ and Clarias gariepinus ${ }^{113}$. The competence of 
feed supplement within the body depends on their size and chemical structure ${ }^{114}$. Additionally, nanoparticles have involved a lot of notice in the region of aquaculture and nanomedicine due to their elite physical, chemical and biological properties ${ }^{13}$. The small components or trace minerals, such as chromium, cobalt, copper, iodine, iron, manganese, molybdenum, selenium and zinc are necessary in small volumes and contribute in an extensive diversity of biochemical processes ${ }^{14}$.

A useful immune system is necessary for the continued existence and activation of shrimp/fish in aquaculture. Every trace mineral factors are contain their exact role in immunity of cultured animals, but the crucial trace metals such as $\mathrm{Zn}, \mathrm{Mn}, \mathrm{Cu}$ and Se that have been linked with an enhancement in immunity or role that maintain immunity. The immune system is uses several methods to detoxify these foreign factors or antigens ${ }^{15}$. The small components have mainly strengthened by the significance of their functions immune protection and antioxidative defence. Feed supplements in nano forms are evaluated to find the different properties between improving growth and immunity through antioxidant consequence to their use in small amount than its bulk counterparts, which increases ration criteria ${ }^{1,16}$.

Different types of metal nanoparticles (NPs) such as Se, Fe, $\mathrm{Cu}, \mathrm{FeO}$, and $\mathrm{ZnO}$ are utilized in aquaculture responsibility ${ }^{17,15}$. The metal oxide nanoparticles mainly, trace metal elements are limited with useful immunostimulants in feed additives to fish, it is a novel delivery system for improving the immune capability and infection resistance against to harmful microbes ${ }^{18}$. Dietary additives of chitosan nanoparticles level $(1.0 \mathrm{~g} / \mathrm{kg}$ diet $)$ are utilized to enhance antioxidants and natural immunity response of Nile tilapia ${ }^{19}$. Similarly, Dietary feed with supplementation of copper nanoelements $\left(80 \mathrm{mg} / \mathrm{kg}^{-1} \mathrm{diet}\right)$ are used to improve the growth, digestive enzyme activities, metabolic enzyme levels, biochemical constituents, antioxidant and non-specific immune response in freshwater prawn (Macrobrachium rosenbergii), post larvae ${ }^{20}$ and red sea bream (Pagrus major) ${ }^{18}$.

Dietary feed with supplementation of iron nanoparticles is used to improve growth and better feed efficiency of Nile tilapia (Oreochromis niloticus) fish compared to the control group ${ }^{21}$. Similarly, dietary feed with supplementations of selenium NPs ( $5 \mathrm{mg} \mathrm{Se} / \mathrm{kg}^{-1}$ ) and magnesium NPs (basal diet+500 mg NanoMg/kg diet) are helpful to enhance better growth conditions compared to control group in diverse fish species ${ }^{22-29}$. Dietary additives of various nano elements such as selenium, zinc and manganese are used to enhance stress resistance and bone mineralization of gilthead sea bream (Sparus aurata) ${ }^{30}$. This review provides information about different types of nano dietary supplements are used to enhance the healthy aquatic production as well as utilized various process methods like dietary administration, types, doses level in different aquatic animals. Fig. 1 showed that the dietary feed additives of nanomaterials in aquatic animals.

Dietarv feed additives of nanomaterials in aquatic animals

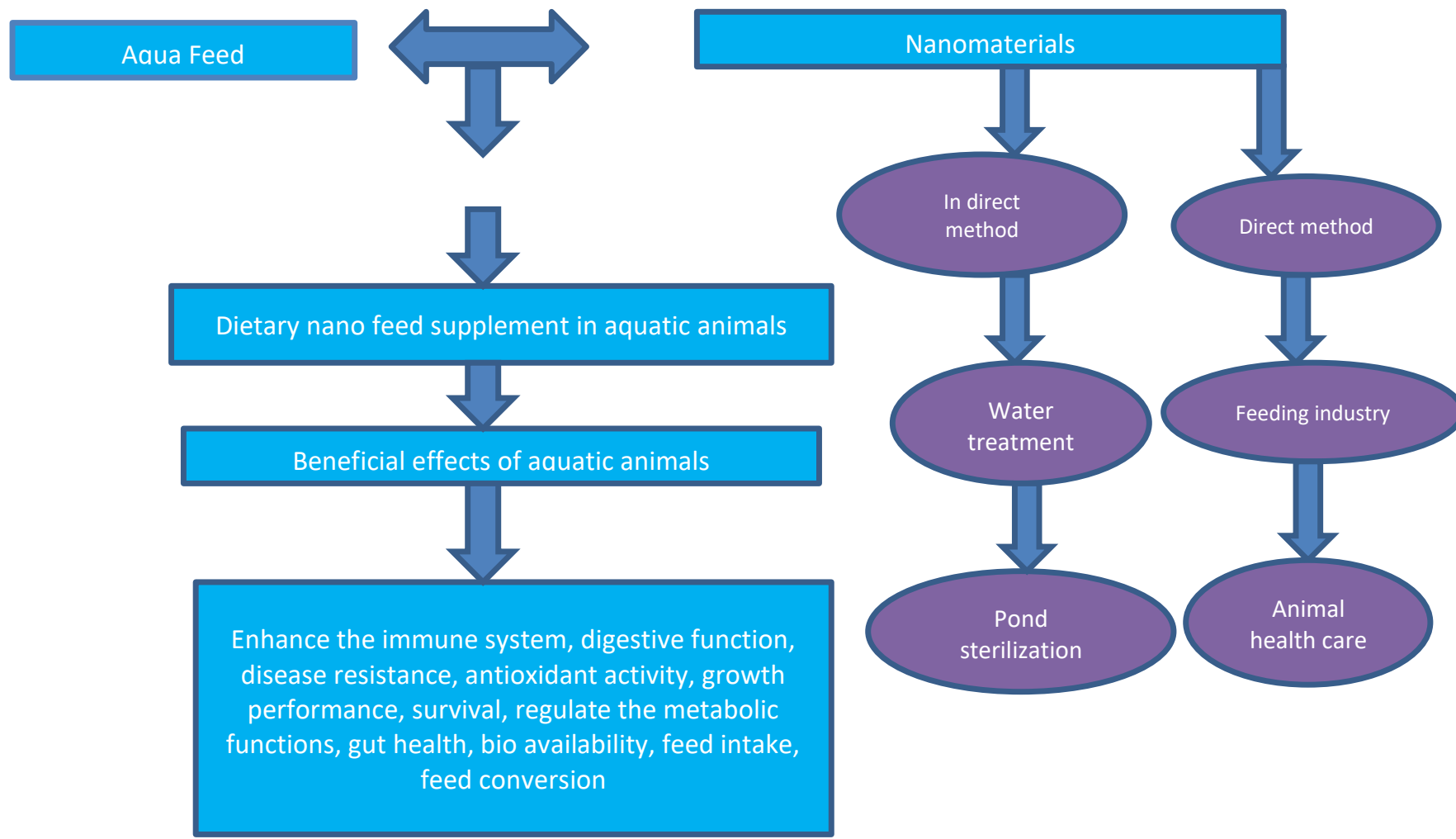

Figure 1: Dietary feed additives of nanomaterials in aquatic animals 
Table 1: The function of different nanomaterials feed additives in aquatic animals

\begin{tabular}{|c|c|c|c|}
\hline Nanomaterials & Aquatic organism & Activity & References \\
\hline Copper & $\begin{array}{l}\text { common carp } \\
\text { M. rosenbergii }\end{array}$ & $\begin{array}{l}\text { 个Immunity } \uparrow \text { Digestive enzyme action, } \\
\text { 个Survival, } \uparrow \text { Growth and } \uparrow \text { Feed intake }\end{array}$ & $\begin{array}{l}(58) \\
(59) \\
(61)\end{array}$ \\
\hline Selenium & $\begin{array}{l}\text { Common carp } \\
\text { Catfish } \\
\text { Meagre } \\
\text { N. tilapia } \\
\text { European seabass }\end{array}$ & $\begin{array}{l}\text { 个Growth performance } \\
\text { 个Feed efficiency } \\
\text { 个Intestinal morphology } \uparrow \text { Antioxidant capability } \uparrow \text { Immune } \\
\text { related gene expression }\end{array}$ & $\begin{array}{l}(26) \\
(62) \\
(63) \\
(64) \\
(65) \\
(74)\end{array}$ \\
\hline Zinc & $\begin{array}{l}\text { M. rosenbergii } \\
\text { Grass carp }\end{array}$ & 个 Survival, $\uparrow$ Growth, and $\uparrow$ Immunity & $\begin{array}{l}(80) \\
(84)\end{array}$ \\
\hline Chitosan & $\begin{array}{l}\text { Rainbow trout } \\
\text { Kelp grouper } \\
\text { Gibel carp }\end{array}$ & $\begin{array}{l}\text { 个Immunity, } \uparrow \text { Stress resistance, } \uparrow \text { Growth and } \uparrow \text { Disease } \\
\text { resistance }\end{array}$ & $\begin{array}{l}(92) \\
(96) \\
(99) \\
(101)\end{array}$ \\
\hline Magnesium & M. rosenbergii & 个 growth, $\uparrow$ Survival and $\uparrow$ Digestive enzyme function & $(116)$ \\
\hline Manganese & $\begin{array}{l}\text { M. rosenbergii } \\
\text { Atlantic salmon } \\
\text { Juvenile tilapia } \\
\text { Channel catfish }\end{array}$ & 个Growth, $\uparrow$ Survival and $\uparrow$ Protein efficiency & $\begin{array}{l}(120) \\
(122) \\
(125) \\
(121)\end{array}$ \\
\hline Iron & $\begin{array}{l}\text { Carp } \\
\text { Nile tilapia }\end{array}$ & $\begin{array}{l}\text { Muscle concentration } \\
\uparrow \text { Growth, } \uparrow \text { Immune response, } \text { Antioxidant activity and } \\
\text { 个Disease resistance }\end{array}$ & $\begin{array}{l}(131) \\
(132)\end{array}$ \\
\hline Chromium & C. mrigala & $\begin{array}{l}\uparrow \text { Growth, } \uparrow \text { Nutrient digestibility and } \uparrow \text { Haematological } \\
\text { parameter }\end{array}$ & $(141)$ \\
\hline
\end{tabular}

\section{Role of nanotechnology in aquaculture}

Nanoparticles synthesized are different kinds of methods such as physical, chemical and biological methods. The significant role of nanoparticle is used for drug delivery and other additives are biological substances across the cell membrane in the biological process. Green synthesis nanoparticles are great attention of other chemical synthesized materials and their combination with the various parts of cell ${ }^{31}$. Traditional methods are not suitable for the synthesis of nanomaterials and these methods are utilizing lot of reagent and chemical for the biggest productions of nano elements both industrial and commercial level ${ }^{31-33}$. Nanoparticles are demonstrated that various responses by cell decrease the mortality rate of fish species. Different kinds of nanomaterials are able to enter antigen-presenting cells by different pathways and stimulate immune responses to the antigen. Role of nanoparticles is designed to perform the specific cell and different kinds of nanomaterials are used in fish vaccine delivery, biodegradable polymers, nano liposomes, carbon nanotubes, calcium phosphate, and immunostimulating complexes $^{34}$.

The nanomaterials are desired in relation to fishes and other organisms via various routes with less negative impacts ${ }^{34-37}$. Nanotechnology is plays a significant function in fish nutrition, drugs and vaccines in efficient manner. Nanotechnology possesses a great attention of novel nanoparticles with cost effective production. Nanoparticles relate field is more niches for researchers and fast growing impacts are providing novel nano-labelled products with unique role ${ }^{38-40}$. Nanoparticles are mainly linked to target with specific antigen of the pathogen and suppress their replication at the cellular level. Fish food is playing a significant role in nutrition, food security and livelihoods ${ }^{41}$.

Fish has provided the high quality of proteins and other nutrients particularly, amino acids, fatty acids, vitamins and other vital elements ${ }^{41}$. Nanotechnological application process are the most important role in aquaculture feed production and the nanoparticles contains to successful prove the micronutrient delivery, quantity produced feed and growth promotion ${ }^{42}$. In addition, chitosin nanoparticles are more encapsulators that are efficient and carriers utilized for oral delivery of vaccines and bioactive substances due to their high resistant to intestinal degradation. These components are more helpful to protect the encapsulated ingredients, increase their shelf life and improve intestinal absorption without cytotoxicity 43, 44. Gastrointestinal microbial diversity in fishes that are strongly involved to control the intestinal immune system depending on the relation between the composition of beneficial and pathogenic microorganisms of the aqua feed nutrients ${ }^{45}$. In addition, beneficial microbes are secreting their digestive enzymes to digest the nutrients via intestines of fish and beneficial microbes are enhancing the feed efficiency and growth rate ${ }^{46}$.

Dietary additives of chitosan nanoparticle are continuously prepared to utilize for fish feed and this nano feed contain the positive impact on anti oxidant activity when orally 
treated for fishes ${ }^{47}$. Dawood et al. (2020) reported that dietary additives chitosan nano elements are utilized to improve the growth performance of feed utilization and intestinal histo morphometric features in L. ramada. In addition, numerous study reports are suggested that role of nanotechnology in effective delivery of dietary feed additives and nutraceuticals in fisheries. These techniques are helpful to improve bioavailability, bio accessibility and the effectiveness of dietary nutrients are enhancing their solubility and defence from unfavourable environment of the gut. Dietary additive of selenium ( $1 \mathrm{mg} / \mathrm{kg}$ ) is used to enhance growth and anti oxidant activity of common carp; these results are confirmed to compare with control groups 48. Nanotechnology is considered solution to prevent and monitor diseases and pathogens and numerous positive effects in aquaculture ${ }^{49}$.

\section{Different kinds of nanoparticles application in aquaculture}

\subsection{Copper nanoparticles (Cu NPs)}

Dietary inorganic copper such as copper oxide, copper chloride and organic chelated copper or nano form of copper is new method of copper dietary feed additives. Recently, many researchers recommended that bioavailability of organic chelated copper is elevated than copper inorganic salts in chick, pig, lamp $50,52,53$ and fishes 54-56. These results indicated that Cu NPs level $(2.59 \mathrm{mg} / \mathrm{kg})$ has been improved the immunity in common carp ${ }^{57}$. Although, the system of action of $\mathrm{Cu}$ NPs on humoral immunity is unidentified, it has been expressed that Cu NPs might not directly control humoral immunity by cellular immune responses 58,59 . The connection between the immunity and against dietary feed with supplementation of $\mathrm{Cu}$ NPs is known by a polynomial model focused on lysozyme action $\left(R^{2}=0.7528 ; P=0.001\right)$. Lysozyme and phagocytic action are focused on the Cu NPs needed for common carp (Cyprinus carpio) (2.59 to $2.68 \mathrm{mg} / \mathrm{kg}$ ) (59). IgM is also improved by $\mathrm{Cu}$ NPs in parallel with Russian sturgeon ${ }^{59}$. The system behind the role of $\mathrm{Cu}$ iron enhancing the immunity of fish is not clear right now, but $\mathrm{Cu}$ iron deficiency is responsible for the immunosuppression, decrease of T cell proliferations and cytokine production ${ }^{60}$. Muralisankar et al. (2016) concluded that the Cu NPs inclusion of dietary feed supplements are used to increasing the digestive enzymes activity, feed intake, better survival, growth with elevated the biochemical constituents and whole body mineral contents in $M$. rosenbergii feed with $\left(20 \mathrm{mg} / \mathrm{kg}^{-1}\right) \mathrm{Cu} N P s$ supplemented diet (Muralisankar et al., 2016). These dietary feed with supplementation level is sustainable culture of freshwater prawn $M$. rosenbergii ${ }^{61}$. The functions of different nanomaterials feed additives in aquatic animals have been summarised in Table 1.

\subsection{Selenium nanoparticles (Se NPs)}

Dietary feed with additives of Se NPs are utilized to enhance growth performance, feed efficiency of several aquatic species such as common carp of Cyprinus carpio ${ }^{26,62}$, catfish of Clarias gariepinus ${ }^{63}$, and meager of Argyrosomus regius 64. Single or combined dietary feed with supplementation of Se NPs and/or Vitamin C is used to enhance intestinal morphology, antioxidant capability, and immune related gene expression in Nile tilapia (Oreochromis niloticus) ${ }^{65}$. Sechitosan is regulates the immune system response by increasing their innate immunity and regulating pathogeninduced inflammation through Toll-like receptor-regulated signalling pathways ${ }^{66,67} \cdot{ }^{68}$ Hoffmann, (2007) and ${ }^{64}$ Mansour et al. (2017) have recommended that Se pretentious immune function by modifiable thyroid hormone metabolism. Moreover, nutritional Se NPs and/or Vitamin C extensively improved superoxide dismutase, glutathione peroxidase, catalase, nitro-blue tetrazolium (NBT) level, the phagocytic index, lysozyme and phagocytic activities ( $P<$ 0.05). However, particularly decreased levels of malonaldehyde are evaluated in fish feed Se NPs and/or VC $(P<0.05)^{64}$.

TNF- $\alpha$ and IL-1 $\beta$ showed gene expressions in the liver and spleen of the fishes are extensively upregulated by Se NPs and/or VC $(P<0.05)$. The results exposed that the possible function of Se NPs and/or VC in improving growth, intestinal morphometry, immune and antioxidative functions in Nile tilapia (Oreochromis niloticus) 68, 64. Dietary feed with supplementation of Se NPs is used to improved physiological parameters, immune response and antioxidant activity in the fish fed diet supplemented with $\left(1 \mathrm{mg} / \mathrm{kg}\right.$ ) of Se NPs ${ }^{69}$. These dietary feed supplements are used to enhance disease resistance; muscle proximate composition and economic efficiency improved with (1 $\mathrm{mg} / \mathrm{kg}$ ) of Se NPs incorporated diet. In addition, the Se necessary by monosex Nile tilapia (Oreochromis niloticus) that results are in best growth performance, feed utilization (1.23 and $1.26 \mathrm{mg} \mathrm{Se} / \mathrm{kg}$ ) and diet respectively ${ }^{69}$. Dietary feed with supplementation of Se NPs are showed that increased the fish body weight, , significant growth ratio, lowest feed conversion ratio compared to Se. The basal diets and also good bio available sources for tilapias growth 70 as well as dietary feed with nano selenium additive are positive impact on several fish species $26,62,71-73$. Dietary feed with additives Se NPs range between 0.5 and $1 \mathrm{mg} / \mathrm{kg}$ is most favourable for growth performance, hematobiochemical indices, antioxidative status, and immunerelated genes in European sea bass (Dicentrarchus labrax) 74.

\subsection{Zinc oxide nanoparticles (ZnO NPs)}

The additional strengthening of ZnO NPs are enhances growth, feed intake, immune reaction, anti-oxidative status, thermal tolerance, reproductive function of animals and response as an antimicrobial factor ${ }^{75-79}$. The ZnO NPs (60 mg/ $\mathrm{kg}^{-1}$ ) are enhanced the survival, growth and immunity of Macrobrachium rosenbergii ${ }^{80}$. The growth of haematological criterion of grass carp and Ctenopharyngodon idella are enhanced with dietary feed with supplementation of ZnO NPs $\left(30 \mathrm{mg} / \mathrm{kg}^{-1}\right)$. In addition, the dietary feed additives with ZnO NPs have better thermal resistance of Pangasius hypophthalmus kept under lead 
contamination and defence this fish against oxidative, cellular metabolic stress ${ }^{77}$. Luo et al. (2015) reported that, ZnO NPs might activate non-specific and specific immune reaction depending on their physicochemical functions. Furthermore, it is well recognized that $\mathrm{Zn}$ irons insufficiency reduces immune reaction and infection resistance in human and animals ${ }^{81}$.

In the recent research reported that dietary feed with additives of ZnO NPs is used to upregulated the IL-1 $1 \beta$ and IL-8 expression profile extensively in $(\mathrm{ZnO} 60 \mathrm{mg} / \mathrm{kg}$ and $\mathrm{ZnO}$ $30 \mathrm{mg} / \mathrm{kg}$ ) supplemented group ${ }^{82}$. Tawfik et al. (2017) reported that the IL1- $\beta$ gene expression in 0 . niloticus subsequent $\mathrm{nZnO}$ and $\mathrm{ZnO}$ as a feed supplement. Our conclusion exposed that, antiprotease occurring in serum is higher than the control group, particularly more action is establish in Ppß-GBP-ZnO NPs than Pp $\beta$-GBP and chem-ZnO NPs supplemented diet fed fish ${ }^{82}$. Antiprotease level in serum of Paralichthys olivaceus enhanced to notably when fed with propolis added diet ${ }^{83}$. Faiz et al. (2015) stated that dietary feed with supplementation of ZnO NPs is utilized to enhance growth and immune status in grass carp (Ctenopharyngodon idella) ${ }^{80}$. Similarly, dietary feed with supplementation of ZnO NPs is used to improve weight, total protein content, digestive enzyme, and antioxidant activity in freshwater prawn of Macrobrachium rosenbergii 84,85 .

Dietary feed with supplementation of ZnO NPs is utilized in low $(30 \mathrm{mg} / \mathrm{kg}$ diet) and high $(60 \mathrm{mg} / \mathrm{kg}$ ) concentration that, high concentration diet can possibly improve immune status and antioxidant status of fish species. On the other side disrupts immune responses and antioxidant status, besides mediating oxidative and inflammatory injuries as well as low concentration diet of ZnO NPs could improve the economics of farming and improve the fish production ${ }^{86}$. Dietary feed with supplementation of ZnO NPs is used in short duration studies ( $\leq 45$ days) for fish species. These dietary feed of nano supplements are used to enhance the growth, feeding efficiency, metabolic enzymes, serum profile and non-specific immune functions in rohu, L. rohita fingerlings and also ZnO NPs supplement is used to increase absorption and bioavailability in the gastrointestinal tract of fish ${ }^{87}$. Dietary feed with supplementation of organic and inorganic ZnO NPs are utilized to enhance growth performance, immunity via modulation of cytokine genes expression, and higher antioxidant activity either in serum or antioxidant gene transcription in $O$. niloticus fish ${ }^{51}$

\subsection{Chitosan nanoparticles (Cs NPs)}

Many researchers suggested that chitosan nanoparticles (CS NPs) are more capable in reducing the growth of Staphylococcus aureus, Candida albicans, Saccharomyces cerevisiae, Escherichia coli, and Fusarium culmorum than ordinary chitosan elements ${ }^{88,89}$. The antibacterial activity of Cs NPs might be documented to its polycationic nature due to the turnout of main amine groups in their frequent units. These amine groups are connect to the negatively charged bacterial cell wall, changing the membrane permeability, troublesome the cell and consequently connecting to the DNA most important to the inhibition of DNA replication and cell death ${ }^{90,91}$. The use of nano-sized materials with stronger immune stimulatory characteristics would be a unique technique in aquaculture industry for getting better fish growth, health, and immunity by changing the existing usual products. Hence, it is speculated that the use of CS NPs may get better feeds characteristics and in turn, may get better fish performance, health and immunity. Immunostimulants be able to be defined as natural or synthetic molecules capable of stimulating nonspecific and/or specific immune responses ${ }^{92}$. The addition of immunostimulants in aquaculture practices is future now.

In recent years, chitosan has been exhibited as a successful immunostimulant in diverse fish species ${ }^{93}$. The role of achievement of immunostimulation result of chitosan within fish body is not fully understood yet. Furthermore, the immunostimulation result of chitosan may through improving the action of inflammatory cells namely polymorphonuclear leucocytes, cytokine, and macrophages ${ }^{94,95}$. The helpful application of chitosan on fish is showed in numerous studies in which Cs NPs are administered via diet. Dietary feed additive with chitosan for Oncorhynchus mykiss 96, Paralichthys olivaceus ${ }^{97}$, Cyprinus rubrofuscus 98, Epinephelus bruneus 99, Scophthalmus maximus ${ }^{100}$, Carassius gibelio ${ }^{101}$, Cirrhinus cirrhosus ${ }^{102}$, and Lates calcarifer ${ }^{103}$ are showed that the chitosan might improve the growth, natural immunity, infection, stress resistance, haematological parameters and water quality. From fish immunological view point, Cs NPs are utilized for the delivery of vitamin C ${ }^{106}$, RNA (107), or DNA 108,109, 113- 115 owing to their positive charge and solubility in aqueous solution. In addition, chitosan is enhances the encapsulated properties of active molecules from the harsh conditions in the gastrointestinal tract and increases their absorption ${ }^{114}$. The efficiency of recombinant DNA-Cs NPs is examined that defence against white spot syndrome virus (WSSV) in shrimps. It is establish that when administered orally, the vaccine improved shrimp immunity, given that a defensive reaction against WSSV ${ }^{115}$.

\subsection{Magnesium nanoparticles (Mg NPs)}

Dietary feed additives of MgO NPs (100-500 mg/ $\mathrm{kg}^{-1}$ ) are used to increase growth, better survival, function of different enzymes like amylase, protease and lipase; and concentration of biochemical components (amino acids, total protein, lipid and carbohydrate) in $M$. rosenbergii PL over the control. This research mentioned that dietary feed additives of MgO NPs (100-500 mg/ kg-1) are utilized to increase general health and non-specific immunity of the test prawns and also these additives level suitable and safe concentration as far as $M$. rosenbergii PL is concerned ${ }^{116}$. Dietary feed additives with Mg NPs are used to reduce the negative impact of magnesium and also smaller particles can easily absorb from intestinal wall of aquatic animals ${ }^{117}$. Single or combined dietary feed with supplementation of nano elements Se NPs and Mg NPs are used to enhanced humoral immunity and improved antioxidant capacity in 
Asian sea bass (Lates calcarifer) ${ }^{29}$ and also Mg NPs having antibacterial and antioxidative effects ${ }^{118,}{ }^{119}$. Srinivasan et al. (2017) reported that dietary feed with supplementation of Mg NPs $(100-500 \mathrm{mg} / \mathrm{kg})$ is used to improve growth performance, non-specific immunity and general health of prawn. However, no information is available about synergistic effect of Se and $\mathrm{Mg}$ in fish ${ }^{116}$.

\subsection{Manganese nanoparticles (Mn NPs)}

Dietary feed with supplementation of Mn NPs $(18 \mathrm{mg} / \mathrm{kg})$ is used to enhance survival, growth, protein efficiency and feed intake of $M$. rosenbergii. Similar studies are reported that dietary feed with supplementation of Mn NPs used to enhance growth performance of diverse fish species such as Cyprinus carpio ${ }^{120}$, Ictalurus punctatus ${ }^{121}$, Salmo salar ${ }^{122}$, Horabagrus brachysoma ${ }^{123}$, Scophthalmus maximus ${ }^{124}$. Oreochromis niloticus ${ }^{125}$, Carassius gibelio ${ }^{126}$, Epinephelus lanceolatus 127, Oncorhynchus mykiss and Ctenopharyngodon idella ${ }^{128}$ and Rachycentron canadum ${ }^{129}$. Muralisankar et al. (2015) reported that dietary feed additives with MnO NPs are used to improve digestive enzymes secretion (protease, amylase and lipase) in $M$. rosenbergii ${ }^{85}$.

\subsection{Iron nanoparticles}

Iron oxide is great potential elements for humans and animals; dietary feed with nano element additive is utilized for aquatic animals and fortified cereals, drinks for human consumption ${ }^{130}$. Dietary feed with additives of metallic nano iron element is consuming positive impact of aquaculture development and also iron nano element used to improve muscle concentration and enhance the growth performance of Cyprinidae ${ }^{131}$. El-Shenawy et al. (2019) reported that dietary feed with supplementation of iron sources like iron oxide or iron NPs $(63.75 \mathrm{mg} / \mathrm{kg})$ are having numerous beneficial effect such as enhanced growth, immune response, phagocytosis activity, reduced mortality rate, protein and lipid content, muscle concentration, RBC,WBC, antioxidant activity, disease resistance in Oreochromis niloticus ${ }^{132}$. Huber (2005) reported that dietary feed with additives of iron oxide nano elements is used to enhance bioavailability of fish species compared to then other form of iron components as well as iron oxide element is highly bio availability ( $96 \%$ similar with $\mathrm{FeSO}_{4}$ ) in rats without tissue accumulation ${ }^{133,134}$.

Dietary feed with supplementation of iron nano elements (30-50 mg/ kg-1) is used enhance digestive enzyme function, food intake, better survival and growth of $M$. rosenbergii ${ }^{135}$. Behera (2014) recommended that nano iron element could have a special metabolism pathway and deposition mechanism in fishes. A reduction of macromolecule to nanoscale has been changed their properties and develops their applications ${ }^{136}$. Metallic iron NPs are unique physico chemical properties and great attention for fish growth and fish feed additives ${ }^{131}$. Dietary feed with supplementation of iron nanomaterial range is suitable $(40 \mathrm{mg} / \mathrm{kg}$ ) to improve fish growth, feed utilization of C.batrachus ${ }^{137}$. Srinivasan et al. (2016) reported that dietary feed with supplementation of iron nano element range $\left(20 \mathrm{mg} / \mathrm{kg}^{-1}\right)$ is suitable for safe concentration for $M$. rosenbergii. This nano element range contains numerous beneficial effects like enhanced growth, survival, and digestive enzyme action, concentrations of total protein, amino acid, carbohydrate and non-specific immunity ${ }^{135}$.

\subsection{Chromium nanoparticles (Cr NPs)}

Dietary feed with additives of chromium nano element is significantly improving insulin like growth factor, immunoglobulin contents in plasma as well decreases level of serum insulin and cortisol ${ }^{138}$. In addition, dietary feed with supplementation of chromium nano element is significantly increases the concentration of chromium in liver, kidney and heart as well as this additive has beneficial impact in carcass characteristics ${ }^{139}$. Dietary feed with additives of $\mathrm{Cr}$ NPs $\left(1.5-2 \mathrm{mg} / \mathrm{Kg}^{-1}\right)$ with sunflower based meal are used to enhance growth performance in C. mrigala fingerlings ${ }^{140}$. Wang et al. (2007) reported that dietary feed with additives of $\mathrm{Cr}$ NPs is significantly improving immunoglobulin in blood plasma ${ }^{138}$. Dietary feed with supplementation of chromium nano element to rate $(2 \mathrm{mg} /$ $\mathrm{Kg}^{-1}$ ) and sunflower based meal diet is helpful to enhance growth, nutrients digestibility and improvement of haematological parameters of $C$. catla fingerlings ${ }^{141}$.

\section{CONCLUDING REMARKS}

In aquaculture industry, NPs are used to develop the different kinds of applications. NPs are utilized in two dissimilar methods such as direct and indirect methods. Indirect method is used to treat waste water, fish pond sterilization and harvested fish packaging for commercialization such as bar coding and tagging and direct method is used to feeding industry and animal health care. Nanotechnology is the modern tool for the development of aquaculture and seafood industries as well as without difficulty to identify different types of bacterial and viral diseases in aquatic animals. In this review concluded that dietary feed with supplementation of different kinds of nano elements are used to enhance immune system, disease resistance, anti oxidant activity, digestive enzyme activity, growth performance and general health development of aquatic animals and also increase the healthy aquatic production. A comprehensive study is needed to helpful for the development of nano dietary feed supplements using in aquaculture applications. This review report helpful for the enhancements of dietary nano feed supplements and develop the modern aquaculture industry as well as this technique is the alternative way to enhance healthy aquatic production. In future studies should be determined on preventing or reducing the unfavourable effects of these materials. 


\section{REFERENCES}

1. Rather MA, Sharma R, Aklakur M, Ahmad S, Kumar N, Khan M, Ramya VL. Nanotechnology: a novel tool for aquaculture and fisheries development. A prospective mini-review. Fisheries and Aquaculture Journal. 2011; 16(1-5):3.

2. Baruah K, Sahu NP, Pal AK, Jain KK, Debnath D, Mukherjee SC Dietary microbial phytase and citric acid synergistically enhances nutrient digestibility and growth performance of Labeo rohita (Hamilton) juveniles at sub-optimal protein level. Aquaculture Research. 2007 Feb; 38(2):109-20. https://doi.org/10.1111/j.13652109.2006.01624.x

3. Zhou QC, Tan BP, Mai KS, Liu YJ. Apparent digestibility of selected feed ingredients for juvenile cobia Rachycentron canadum. Aquaculture. $2004 \quad$ Nov 26; 241(1-4):441-51. https://doi.org/10.1016/j.aquaculture.2004.08.044

4. Tawfik M, Moustafa M, Abumourad IM, El-Meliegy E, Refai M Evaluation of Nano Zinc Oxide feed additive on tilapia Growth and Immunity. In15th International Conference on Environmental Science and Technology, Rhodes, Greece 2017 Aug (Vol. 1342, No. 1, pp. 1-9).

5. Mohanty BP. Nutritional value of food fish. Conspectus of Inland Fisheries Management. 2015; 4:15-21.

6. Menanteau-Ledouble S, Krauss I, Santos G, Fibi S, Weber B, ElMatbouli M. Effect of a phytogenic feed additive on the susceptibility of Onchorhynchus mykiss to Aeromonas salmonicida. Diseases of aquatic organisms. 2015 Jun 29; 115(1):57-66. DOI: https://doi.org/10.3354/dao02875

7. Menanteau-Ledouble S, Krauss I, Goncalves RA, Weber B, Santos GA, El-Matbouli M. Antimicrobial effect of the Biotronic ${ }^{\circledR}$ Top3 supplement and efficacy in protecting rainbow trout (Oncorhynchus mykiss) from infection by Aeromonas salmonicida subsp. salmonicida. Research in veterinary science. 2017 Oct 1; 114:95-100. https://doi.org/10.1016/j.rvsc.2017.03.010

8. Bunglavan SJ, Garg AK, Dass RS, Shrivastava S. Use of nanoparticles as feed additives to improve digestion and absorption in livestock. Livest. Res. Int. 2014; 2(3):36-47.

9. Sharma A, Qiang Y, Antony J, Meyer D, Kornacki P, Paszczynski A. Dramatic increase in stability and longevity of enzymes attached to monodispersive iron nanoparticles. IEEE transactions on magnetics. 2007 May 21; 43(6):2418-20. DOI: 10.1109/TMAG.2007.893849

10. Dar AH, Rashid N, Majid I, Hussain S, Dar MA. Nanotechnology interventions in aquaculture and seafood preservation. Critical reviews in food science and nutrition. 2020 Jun 16;60(11):1912-21. https://doi.org/10.1080/10408398.2019.1617232

11. Khan HA, Mukhopadhay SK. Observation on the effects of yeast and cobalt chloride in increasing the survival rate of the hatchlings of Heteropneustesfossilis (Bloch). InSymposium on Trends of Research in Zoology. Zoological Society, Calcutta 1971 (p. 1).

12. Alishahi A, Mirvaghefi A, Tehrani MR, Farahmand H, Koshio $S$ Dorkoosh FA, Elsabee MZ. Chitosan nanoparticle to carry vitamin C through the gastrointestinal tract and induce the non-specific immunity system of rainbow trout (Oncorhynchus mykiss). Carbohydrate polymers. 2011 Aug 1; 86(1):142-6. https://doi.org/10.1016/j.carbpol.2011.04.028

13. Sharma VK, Yngard RA, Lin Y. Silver nanoparticles: green synthesis and their antimicrobial activities. Advances in colloid and interface science. $2009 \quad$ Jan 30; 145(1-2):83-96. https://doi.org/10.1016/j.cis.2008.09.002

14. Antony Jesu Prabhu $P$, Schrama JW, Fontagné-Dicharry $S$, Mariojouls C, Surget A, Bueno M, Geurden I, Kaushik SJ. Evaluating dietary supply of microminerals as a premix in a complete plant ingredient-based diet to juvenile rainbow trout (Oncorhynchus mykiss). Aquaculture Nutrition. 2018 Feb; 24(1):539-47. https://doi.org/10.1111/anu.12586

15. El Basuini MF, El-Hais AM, Dawood MA, Abou-Zeid AE, EL-Damrawy SZ, Khalafalla MM, Koshio S, Ishikawa M, Dossou S. Effect of different levels of dietary copper nanoparticles and copper sulfate on growth performance, blood biochemical profiles, antioxidant status and immune response of red sea bream (Pagrus major) $\begin{array}{llll}\text { Aquaculture. } & 2016 \quad \text { Mar 20;455:32-40. }\end{array}$ https://doi.org/10.1016/j.aquaculture.2016.01.007

16. Rajendran D. Application of nano minerals in animal production system. Research Journal of Biotechnology. 2013 Mar 1;8(3):1-3.

17. Srinivasan V, Bhavan PS, Rajkumar G, Satgurunathan T, Muralisankar T. Effects of dietary iron oxide nanoparticles on the growth performance, biochemical constituents and physiological stress responses of the giant freshwater prawn Macrobrachium rosenbergii post-larvae. International Journal of Fisheries and Aquatic Studies. 2016;4(2):170-82.

18. El Basuini MF, El-Hais AM, Dawood MA, Abou-Zeid AS, El-Damrawy SZ, Khalafalla MS, Koshio S, Ishikawa M, Dossou SJ. Effects of dietary copper nanoparticles and vitamin $C$ supplementations on growth performance, immune response and stress resistance of red sea bream, Pagrus major. Aquaculture Nutrition. 2017 Dec;23(6):132940. https://doi.org/10.1016/i.aquaculture.2016.01.007

19. Abdel-Tawwab $M$, Razek NA, Abdel-Rahman AM Immunostimulatory effect of dietary chitosan nanoparticles on the performance of Nile tilapia, Oreochromis niloticus (L.). Fish \& shellfish immunology. 2019 May 1;88:254-8. https://doi.org/10.1016/j.fsi.2019.02.063

20. Muralisankar T, Bhavan PS, Radhakrishnan S, Seenivasan C, Srinivasan V. The effect of copper nanoparticles supplementation on freshwater prawn Macrobrachium rosenbergii post larvae. Journal of Trace Elements in Medicine and Biology. 2016 Mar 1;34:39-49. https://doi.org/10.1016/j.jtemb.2015.12.003

21. Roedar M, Roedar RH. Effect of iron on the growth rate of fish. J. Nutr. 1968;90:86-90.

22. Jaramillo Jr F, Peng LI, Gatlin lii DM. Selenium nutrition of hybrid striped bass (Morone chrysops $\times$ M. saxatilis) bioavailability, toxicity and interaction with vitamin E. Aquaculture nutrition. 2009 Apr;15(2):160-5. $\underline{2095.2008 .00579 . x}$

23. Han D, Xie S, Liu M, Xiao X, Liu H, Zhu X, Yang Y. The effects of dietary selenium on growth performances, oxidative stress and tissue selenium concentration of gibel carp (Carassius auratus gibelio). Aquaculture Nutrition. 2011 Jun;17(3):e741-9. https://doi.org/10.1111/i.1365-2095.2010.00841.x

24. Liu K, Wang XJ, Ai Q, Mai K, Zhang W. Dietary selenium requirement for juvenile cobia, Rachycentron canadum L. Aquaculture Research. 2010 Sep;41(10):e594-601. https://doi.org/10.1111/j.13652109.2010.02562.x

25. Wang $D$, Zhao $L$, Tan $Y$. Requirement of the fingerling grass carp (Ctenopharyngodon idellus) for choline. Journal of Fisheries of China. 1995;19(2):133-9.

26. Ashouri S, Keyvanshokooh S, Salati AP, Johari SA, Pasha-Zanoosi $H$. Effects of different levels of dietary selenium nanoparticles on growth performance, muscle composition, blood biochemical profiles and antioxidant status of common carp (Cyprinus carpio). Aquaculture. $2015 \quad$ Sep 1;446:25-9. https://doi.org/10.1016/j.aquaculture.2015.04.021

27. Ilham I, Fotedar R. Growth, enzymatic glutathione peroxidase activity and biochemical status of juvenile barramundi (Lates calcarifer) fed dietary fermented soybean meal and organic selenium. Fish physiology and biochemistry. 2017 Jun 1;43(3):775. DOI:10.1007/s10695-016-0331-2

28. Seiedi J, Kalbassi MR. Effects of different levels of diet nano selenium (Nano-Se) on growth and gonad quality indices and seminal plasma antioxidants in male goldfish (Carassius auratus gibelio). Aquatics Physiology and Biotechnology. 2017 Aug 23;5(2):67-82.

29. Longbaf Dezfouli M, Ghaedtaheri A, Keyvanshokooh S, Salati AP, Mousavi SM, Pasha-Zanoosi H. Combined or individual effects of dietary magnesium and selenium nanoparticles on growth performance, immunity, blood biochemistry and antioxidant status of Asian seabass (Lates calcarifer) reared in freshwater. Aquaculture Nutrition. $2019 \quad$ Dec;25(6):1422-30. https://doi.org/10.1111/anu.12962 
30. Izquierdo MS, Ghrab W, Roo J, Hamre K, Hernández-Cruz CM, Bernardini G, Terova G, Saleh R. Organic, inorganic and nanoparticles of Se, $\mathrm{Zn}$ and $\mathrm{Mn}$ in early weaning diets for gilthead seabream (Sparus aurata; Linnaeus, 1758). Aquaculture Research. 2017 Jun;48(6):2852-67. https://doi.org/10.1111/are.13119

31. Delgado CL. Fish to 2020: Supply and demand in changing globa markets. WorldFish; 2003.

32. Kok B, Malcorps W, Tlusty MF, Eltholth MM, Auchterlonie NA, Little DC, Harmsen R, Newton RW, Davies SJ. Fish as feed: Using economic allocation to quantify the Fish In: Fish Out ratio of major fed aquaculture species. Aquaculture. 2020 Nov 15;528:735474. https://doi.org/10.1016/i.aquaculture.2020.735474

33. Olmos J, Acosta M, Mendoza G, Pitones V. Bacillus subtilis, an ideal probiotic bacterium to shrimp and fish aquaculture that increase feed digestibility, prevent microbial diseases, and avoid water pollution. Archives of microbiology. 2020 Apr;202(3):427-35. https://doi.org/10.1007/s00203-019-01757-2

34. Shaalan MI, El-Mahdy MM, Theiner S, El-Matbouli M, Saleh M. In vitro assessment of the antimicrobial activity of silver and zinc oxide nanoparticles against fish pathogens. Acta Veterinaria Scandinavica. 2017 Dec;59(1):1-1. https://doi.org/10.1186/s13028017-0317-9

35. Tanaka M, Münsterberg A, Anderson WG, Prescott AR, Hazon N, Tickle $C$. Fin development in a cartilaginous fish and the origin of vertebrate limbs. Nature. 2002 Apr;416(6880):527-31. https://doi.org/10.1038/416527a

36. Schirmer K. Proposal to improve vertebrate cell cultures to establish them as substitutes for the regulatory testing of chemicals and effluents using fish. Toxicology. 2006 Jul 25;224(3):163-83. https://doi.org/10.1016/j.tox.2006.04.042

37. Jaillon $\mathrm{O}$, Aury JM, Brunet F, Petit JL, Stange-Thomann N, Mauceli E, Bouneau L, Fischer C, Ozouf-Costaz C, Bernot A, Nicaud S. Genome duplication in the teleost fish Tetraodon nigroviridis reveals the early vertebrate proto-karyotype. Nature. 2004 Oct;431(7011):94657. https://doi.org/10.1038/nature03025

38. Malhotra N, Ger TR, Uapipatanakul B, Huang JC, Chen KH, Hsiao CD Review of copper and copper nanoparticle toxicity in fish. Nanomaterials. $2020 \quad$ Jun;10(6):1126. https://doi.org/10.3390/nano10061126

39. Marimuthu S, Antonisamy AJ, Malayandi S, Rajendran K, Tsai PC, Pugazhendhi A, Ponnusamy VK. Silver nanoparticles in dye effluent treatment: A review on synthesis, treatment methods, mechanisms, photocatalytic degradation, toxic effects and mitigation of toxicity. Journal of Photochemistry and Photobiology B: Biology. $2020 \quad$ Apr 1;205:111823. https://doi.org/10.1016/i.jphotobiol.2020.111823

40. Munawar N. Interaction and Applications of Nanoparticles in Fishes and Aquaculture. Sch Bull. 2021;7(6):150-5.

41. Kwasek K, Thorne-Lyman AL, Phillips M. Can human nutrition be improved through better fish feeding practices? a review paper. Critical Reviews in Food Science and Nutrition. 2020 Dec 15;60(22):3822-35. https://doi.org/10.1080/10408398.2019.1708698

42. Khosravi-Katuli K, Prato E, Lofrano G, Guida M, Vale G, Libralato G. Effects of nanoparticles in species of aquaculture interest. Environmental Science and Pollution Research. 2017 Jul;24(21):17326-46. https://doi.org/10.1007/s11356-017-9360-3

43. Alishahi A, Mirvaghefi A, Tehrani MR, Farahmand $H$, Shojaosadati SA, Dorkoosh FA, Elsabee MZ. Shelf life and delivery enhancement of vitamin C using chitosan nanoparticles. Food Chemistry. 2011 Jun 1;126(3):935-40. https://doi.org/10.1016/j.foodchem.2010.11.086

44. Wisdom KS, Bhat IA, Kumar P, Pathan MK, Chanu TI, Walke P, Sharma R. Fabrication of chitosan nanoparticles loaded with aromatase inhibitors for the advancement of gonadal development in Clarias magur (Hamilton, 1822). Aquaculture. 2018 Dec 1;497:125-33. https://doi.org/10.1016/j.aquaculture.2018.07.049

45. Encarnação P. Functional feed additives in aquaculture feeds. InAquafeed formulation 2016 Jan 1 (pp. 217-237). Academic Press. https://doi.org/10.1016/B978-0-12-800873-7.00005-1
46. Dawood MA, Zommara M, Eweedah NM, Helal Al, Aboel-Darag MA The potential role of nano-selenium and vitamin $C$ on the performances of Nile tilapia (Oreochromis niloticus). Environmental Science and Pollution Research. 2020 Jan 11:1-0. https://doi.org/10.1007/s11356-020-07651-5

47. Ahmed F, Soliman FM, Adly MA, Soliman HA, El-Matbouli M, Saleh $M$. Recent progress in biomedical applications of chitosan and its nanocomposites in aquaculture: A review. Research in veterinary science. $2019 \quad$ Oct $1 ; 126: 68-82$. https://doi.org/10.1016/j.rvsc.2019.08.005

48. Flemming HC. Biofouling in water systems-cases, causes and countermeasures. Applied microbiology and biotechnology. 2002 Sep;59(6):629-40. https://doi.org/10.1007/s00253-002-1066-9

49. Nasr-Eldahan S, Nabil-Adam A, Shreadah MA, Maher AM, Ali TE. A review article on nanotechnology in aquaculture sustainability as a novel tool in fish disease control. Aquaculture International. 2021 Mar 5:1-22. https://doi.org/10.1007/s10499-021-00677-7

50. Mondal MK, Das TK, Biswas P, Samanta CC, Bairagi B. Influence of dietary inorganic and organic copper salt and level of soybean oil on plasma lipids, metabolites and mineral balance of broiler chickens. Animal feed science and technology. 2007 Dec 15;139(3-4):212-33. https://doi.org/10.1016/j.anifeedsci.2007.01.014

51. Kishawy AT, Roushdy EM, Hassan FA, Mohammed HA, Abdelhakim TM. Comparing the effect of diet supplementation with different zinc sources and levels on growth performance, immune response and antioxidant activity of tilapia, Oreochromis niloticus. Aquaculture Nutrition. 2020 Dec;26(6):1926-42. https://doi.org/10.1111/anu.13135

52. Veum TL, Carlson MS, Wu CW, Bollinger DW, Ellersieck MR. Copper proteinate in weanling pig diets for enhancing growth performance and reducing fecal copper excretion compared with copper sulfate. Journal of animal science. 2004 Apr 1;82(4):1062-70. https://doi.org/10.1093/ansci/82.4.1062

53. Senthilkumar P, Nagalakshmi D, Reddy YR, Sudhakar K. Effect of different level and source of copper supplementation on immune response and copper dependent enzyme activity in lambs. Tropical animal health and production. 2009 Apr;41(4):645-53. https://doi.org/10.1007/s11250-008-9236-0

54. Apines-Amar MJ, Satoh S, Caipang CM, Kiron V, Watanabe T, Aoki T. Amino acid-chelate: a better source of $\mathrm{Zn}, \mathrm{Mn}$ and $\mathrm{Cu}$ for rainbow trout, Oncorhynchus mykiss. Aquaculture. 2004 Oct 27;240(14):345-58. https://doi.org/10.1016/j.aquaculture.2004.01.032

55. Apines MJ, Satoh S, Kiron V, Watanabe T, Fujita S. Bioavailability and tissue distribution of amino acidchelated trace elements in rainbow trout Oncorhynchus mykiss. Fisheries science. 2003;69(4):722-30. https://doi.org/10.1046/i.1444-2906.2003.00679.x

56. Lin YH, Shih CC, Kent M, Shiau SY. Dietary copper requirement reevaluation for juvenile grouper, Epinephelus malabaricus, with an organic copper source. Aquaculture. 2010 Dec 22;310(1-2):173-7. https://doi.org/10.1016/j.aquaculture.2010.10.004

57. Paripatananont T, Lovell RT. Chelated zinc reduces the dietary zinc requirement of channel catfish, Ictalurus punctatus. Aquaculture. 1995 May 15;133(1):73-82. https://doi.org/10.1016/00448486(94)00404-C

58. Ates M, Dugo MA, Demir V, Arslan Z, Tchounwou PB. Effect of copper oxide nanoparticles to sheepshead minnow (Cyprinodon variegatus) at different salinities. Digest Journal of Nanomaterials and Biostructures. 2014 Jan 1;9(1):369. PMID: 25411584

59. Wang H, Zhu H, Wang X, Li E, Du Z, Qin J, Chen L. Comparison of copper bioavailability in copper-methionine, nano-copper oxide and copper sulfate additives in the diet of Russian sturgeon Acipenser gueldenstaedtii. Aquaculture. 2018 Jan 1;482:146-54. https://doi.org/10.1016/j.aquaculture.2017.09.037

60. Dorton KL, Engle TE, Hamar DW, Siciliano PD, Yemm RS. Effects of copper source and concentration on copper status and immune function in growing and finishing steers. Animal Feed Science and Technology. $2003 \quad$ Nov 11;110(1-4):31-44. https://doi.org/10.1016/i.anifeedsci.2003.07.002 
61. Muralisankar T, Bhavan PS, Radhakrishnan S, Seenivasan C, Srinivasan V. The effect of copper nanoparticles supplementation on freshwater prawn Macrobrachium rosenbergii post larvae. Journal of Trace Elements in Medicine and Biology. 2016 Mar 1;34:39-49. https://doi.org/10.1016/i.jtemb.2015.12.003

62. Saffari S, Keyvanshokooh S, Zakeri M, Johari SA, Pasha-Zanoosi HJ. Effects of different dietary selenium sources (sodium selenite, selenomethionine and nanoselenium) on growth performance, muscle composition, blood enzymes and antioxidant status of common carp (Cyprinus carpio). Aquaculture Nutrition. 2017 Jun;23(3):611-7. https://doi.org/10.1111/anu.12428

63. Chris UO, Singh NB, Agarwal A. Nanoparticles as feed supplement on Growth behaviour of Cultured Catfish (Clarias gariepinus) fingerlings. Materials Today: Proceedings. 2018 Jan 1;5(3):9076-81. https://doi.org/10.1016/j.matpr.2017.10.023

64. Mansour AT, Goda AA, Omar EA, Khalil HS, Esteban MÁ. Dietary supplementation of organic selenium improves growth, survival, antioxidant and immune status of meagre, Argyrosomus regius, juveniles. Fish \& shellfish immunology. 2017 Sep 1;68:516-24. https://doi.org/10.1016/j.fsi.2017.07.060

65. Dawood MA, Gewaily MS, Soliman AA, Shukry M, Amer AA, Younis EM, Abdel-Warith AW, Van Doan H, Saad AH, Aboubakr M, AbdelLatif HM. Marine-derived chitosan nanoparticles improved the intestinal histo-morphometrical features in association with the health and immune response of Grey Mullet (Liza ramada). Marine Drugs. 2020 Dec;18(12):611. https://doi.org/10.3390/md18120611

66. Ninawe AS, Selvin J. Probiotics in shrimp aquaculture: avenues and challenges. Critical reviews in microbiology. 2009 Feb 1;35(1):4366. https://doi.org/10.1080/10408410802667202

67. Rombout JH, Abelli L, Picchietti S, Scapigliati G, Kiron V. Teleost intestinal immunology. Fish \& shellfish immunology. 2011 Nov 1;31(5):616-26. https://doi.org/10.1016/j.fsi.2010.09.001

68. Hoffmann PR. Mechanisms by which selenium influences immune responses. Archivum immunologiae et therapiae experimentalis. 2007 Oct;55(5):289-97. https://doi.org/10.1007/s00005-007-0036$\underline{4}$

69. Rathore SS, Murthy HS, Abdullah-AI Mamun M, Nasren S, Rakesh K, Kumar BT, Abhiman PB, Khandagale AS. Nano-selenium Supplementation to Ameliorate Nutrition Physiology, Immune Response, Antioxidant System and Disease Resistance Against Aeromonas hydrophila in Monosex Nile Tilapia (Oreochromis niloticus). Biological Trace Element Research. 2020 Oct 6:1-6. https://doi.org/10.1007/s12011-020-02416-0

70. Wang Y, Yan X, Fu L. Effect of selenium nanoparticles with different sizes in primary cultured intestinal epithelial cells of crucian carp, Carassius auratus gibelio. International Journal of Nanomedicine. 2013;8:4007. PMID: 24204137

71. Wang $Y$, Han J, Li W, Xu Z. Effect of different selenium source on growth performances, glutathione peroxidase activities, muscle composition and selenium concentration of allogynogenetic crucian carp (Carassius auratus gibelio). Animal Feed Science and

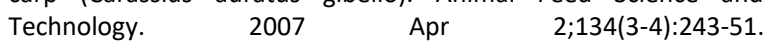
https://doi.org/10.1016/i.anifeedsci.2006.12.007

72. Saffari S, Keyvanshokooh S, Zakeri M, Johari SA, Pasha-Zanoosi H, Mozanzadeh MT. Effects of dietary organic, inorganic, and nanoparticulate selenium sources on growth, hematoimmunological, and serum biochemical parameters of common carp (Cyprinus carpio). Fish physiology and biochemistry. 2018 Aug;44(4):1087-97. https://doi.org/10.1007/s10695-018-0496-y

73. Kohshahi AJ, Sourinejad I, Sarkheil M, Johari SA. Dietary cosupplementation with curcumin and different selenium sources (nanoparticulate, organic, and inorganic selenium): influence on growth performance, body composition, immune responses, and glutathione peroxidase activity of rainbow trout (Oncorhynchus mykiss). Fish physiology and biochemistry. 2019 Apr;45(2):793-804. https://doi.org/10.1007/s10695-018-0585-y

74. Abd El-Kader MF, El-Bab AF, Abd-Elghany MF, Abdel-Warith AW, Younis EM, Dawood MA. Selenium nanoparticles act potentially on the growth performance, hemato-biochemical indices, antioxidative, and immune-related genes of European Seabass (Dicentrarchus labrax). Biological Trace Element Research. 2020 Oct 15:1-9. https://doi.org/10.1007/s12011-020-02431-1

75. Lin S, Lin X, Yang Y, Li F, Luo L. Comparison of chelated zinc and zinc sulfate as zinc sources for growth and immune response of shrimp (Litopenaeus vannamei). Aquaculture. 2013 Aug 25;406:79-84. https://doi.org/10.1016/i.aquaculture.2013.04.026

76. Tsai YH, Mao SY, Li MZ, Huang JT, Lien TF. Effects of nanosize zinc oxide on zinc retention, eggshell quality, immune response and serum parameters of aged laying hens. Animal feed science and technology. $2016 \quad$ Mar 1;213:99-107. https://doi.org/10.1016/i.anifeedsci.2016.01.009

77. Kumar N, Krishnani KK, Kumar P, Jha AK, Gupta SK, Singh NP. Dietary zinc promotes immuno-biochemical plasticity and protects fish against multiple stresses. Fish \& shellfish immunology. 2017 Mar 1;62:184-94. https://doi.org/10.1016/j.fsi.2017.01.017

78. Kumar N, Chandan NK, Wakchaure GC, Singh NP. Synergistic effect of zinc nanoparticles and temperature on acute toxicity with response to biochemical markers and histopathological attributes in fish. Comparative Biochemistry and Physiology Part C: Toxicology \& Pharmacology. $2020 \quad$ Mar 1;229:108678. https://doi.org/10.1016/j.cbpc.2019.108678

79. Muralisankar T, Bhavan PS, Radhakrishnan S, Seenivasan C, Manickam N, Srinivasan V. Dietary supplementation of zinc nanoparticles and its influence on biology, physiology and immune responses of the freshwater prawn, Macrobrachium rosenbergii. Biological trace element research. 2014 Jul;160(1):56-66. https://doi.org/10.1007/s12011-014-0026-4

80. Faiz H, Zuberi A, Nazir S, Rauf M, Younus N. Zinc oxide, zinc sulfate and zinc oxide nanoparticles as source of dietary zinc: comparative effects on growth and hematological indices of juvenile grass carp (Ctenopharyngodon idella). International Journal of Agriculture and Biology. 2015 Jun 1;17(3). DOI: 10.17957/IJAB/17.3.14.446

81. Luo YH, Chang LW, Lin P. Metal-based nanoparticles and the immune system: activation, inflammation, and potential applications. BioMed research international. 2015 Jun 1;2015. https://doi.org/10.1155/2015/143720

82. Tawfik M, Moustafa M, Abumourad IM, El-Meliegy E, Refai M. Evaluation of Nano Zinc Oxide feed additive on tilapia Growth and Immunity. In15th International Conference on Environmental Science and Technology, Rhodes, Greece 2017 Aug (Vol. 1342, No. 1, pp. 1-9).

83. Herland $H$, Cooper M, Esaiassen M, Olsen RL. Effects of dietary mineral supplementation on quality of fresh and salt-cured fillets from farmed Atlantic cod, Gadus morhua. Journal of the World Aquaculture Society. $2011 \quad$ Apr;42(2):261-7. doi/epdf/10.1111/j.1749-7345.2011.00462.x

84. Muralisankar T, Bhavan PS, Radhakrishnan S, Seenivasan C, Manickam N, Srinivasan V. Dietary supplementation of zinc nanoparticles and its influence on biology, physiology and immune responses of the freshwater prawn, Macrobrachium rosenbergii. Biological trace element research. 2014 Jul;160(1):56-66. https://doi.org/10.1007/s12011-014-0026-4

85. Muralisankar T, Bhavan PS, Radhakrishnan S, Seenivasan C, Srinivasan V, Santhanam P. Effects of dietary zinc on the growth, digestive enzyme activities, muscle biochemical compositions, and antioxidant status of the giant freshwater prawn Macrobrachium rosenbergii. Aquaculture. 2015 Nov 1;448:98-104. https://doi.org/10.1016/j.aquaculture.2015.05.045

86. Awad A, Zaglool AW, Ahmed SA, Khalil SR. Transcriptomic profile change, immunological response and disease resistance of Oreochromis niloticus fed with conventional and Nano-Zinc oxide dietary supplements. Fish \& shellfish immunology. 2019 Oct 1;93:336-43. https://doi.org/10.1016/j.fsi.2019.07.067

87. Mondal AH, Behera T, Swain P, Das R, Sahoo SN, Mishra SS, Das J, Ghosh K. Nano zinc vis-à-vis inorganic Zinc as feed additives: Effects on growth, activity of hepatic enzymes and non-specific immunity in rohu, Labeo rohita (Hamilton) fingerlings. Aquaculture Nutrition. 2020 Aug;26(4):1211-22. https://doi.org/10.1111/anu.13077 
88. Yun YS, Kim KS, Lee YN. Antibacterial and antifungal effect of chitosan. J. Chitin Chitosan. 1999;4(1):8-14.

89. Jung BO, Chung SJ, Lee GW. Effect of molecular weight of chitosan on its antimicrobial activity. Journal of Chitin and Chitosan. 2002;7(4):231-6

90. Nagy A, Harrison A, Sabbani S, Munson Jr RS, Dutta PK, Waldman WJ. Silver nanoparticles embedded in zeolite membranes: release of silver ions and mechanism of antibacterial action. International journal of nanomedicine. 2011;6:1833. PMID: 21931480

91. Divya K, Vijayan S, George TK, Jisha MS. Antimicrobial properties of chitosan nanoparticles: Mode of action and factors affecting activity. Fibers and polymers. 2017 Feb 1;18(2):221-30. https://doi.org/10.1007/s12221-017-6690-1

92. Abdel-Ghany HM, Salem ME. Effects of dietary chitosan supplementation on farmed fish; a review. Reviews in Aquaculture. 2020 Feb;12(1):438-52. https://doi.org/10.1111/raq.12326

93. Anderson DP. Immunostimulants, adjuvants, and vaccine carriers in fish: applications to aquaculture. Annual Review of Fish Diseases. 1992 Jan 1;2:281-307. https://doi.org/10.1016/09598030(92)90067-8

94. Shibata Y, Foster LA, Metzger WJ, Myrvik QN. Alveolar macrophage priming by intravenous administration of chitin particles, polymers of N-acetyl-D-glucosamine, in mice. Infection and immunity. 1997 May;65(5):1734-41. doi/abs/10.1128/iai.65.5.1734-1741.1997

95. Ueno $\mathrm{H}$, Mori T, Fujinaga T. Topical formulations and wound healing applications of chitosan. Advanced drug delivery reviews. $2001 \mathrm{Nov}$ 5;52(2):105-15. https://doi.org/10.1016/S0169-409X(01)00189-2

96. Meshkini S, Tafy AA, Tukmechi A, Farhang-Pajuh F. Effects of chitosan on hematological parameters and stress resistance in rainbow trout (Oncorhynchus mykiss). InVeterinary Research Forum 2012 (Vol. 3, No. 1, p. 49). Faculty of Veterinary Medicine, Urmia University, Urmia, Iran. PMID: 25653746

97. Cha SH, Lee JS, Song CB, Lee KJ, Jeon YJ. Effects of chitosan-coated diet on improving water quality and innate immunity in the olive flounder, Paralichthys olivaceus. Aquaculture. 2008 Jun 10;278(14):110-8. https://doi.org/10.1016/j.aquaculture.2008.01.025

98. Lin S, Pan Y, Luo L, Luo L. Effects of dietary $\beta$-1, 3-glucan, chitosan or raffinose on the growth, innate immunity and resistance of koi (Cyprinus carpio koi). Fish \& shellfish immunology. 2011 Dec 1;31(6):788-94. https://doi.org/10.1016/i.fsi.2011.07.013

99. Harikrishnan R, Kim JS, Balasundaram C, Heo MS. Immunomodulatory effects of chitin and chitosan enriched diets in Epinephelus bruneus against Vibrio alginolyticus infection. Aquaculture. 2012 Jan 25;326:46-52. https://doi.org/10.1016/i.aquaculture.2011.11.034

100. Cui L, Xu W, Ai Q, Wang D, Mai K. Effects of dietary chitosan oligosaccharide complex with rare earth on growth performance and innate immune response of turbot, $\mathrm{S}$ cophthalmus maximus $\mathrm{L}$. Aquaculture Research. $2013 \quad$ Apr;44(5):683-90. https://doi.org/10.1111/j.1365-2109.2011.03072.x

101. Chen Y, Zhu X, Yang Y, Han D, Jin J, Xie S. Effect of dietary chitosan on growth performance, haematology, immune response, intestine morphology, intestine microbiota and disease resistance in gibel carp (C arassius auratus gibelio). Aquaculture nutrition. 2014 Oct;20(5):532-46. https://doi.org/10.1111/anu.12106

102. Mari LS, Jagruthi C, Anbazahan SM, Yogeshwari G, Thirumurugan R, Arockiaraj J, Mariappan P, Balasundaram C, Harikrishnan R. Protective effect of chitin and chitosan enriched diets on immunity and disease resistance in Cirrhina mrigala against Aphanomyces invadans. Fish \& shellfish immunology. 2014 Aug 1;39(2):378-85. https://doi.org/10.1016/i.fsi.2014.05.027

103. Ranjan R, Prasad KP, Vani T, Kumar R. Effect of dietary chitosan on haematology, innate immunity and disease resistance of Asian seabass Lates calcarifer (Bloch). Aquaculture Research. 2014 May;45(6):983-93. https://doi.org/10.1111/are.12050

104. Khan KU, Zuberi A, Nazir S, Ullah I, Jamil Z, Sarwar H. Synergistic effects of dietary nano selenium and vitamin $C$ on growth, feeding, and physiological parameters of mahseer fish (Tor putitora).
Aquaculture $\quad$ Reports. $2017 \quad$ Feb 1;5:70-5. https://doi.org/10.1016/i.aqrep.2017.01.002

105. Li J, Cai C, Li J, Li J, Li J, Sun T, Wang L, Wu H, Yu G. Chitosan-based nanomaterials for drug delivery. Molecules. 2018 Oct;23(10):2661. https://doi.org/10.3390/molecules23102661

106. Alishahi A, Mirvaghefi A, Tehrani MR, Farahmand H, Koshio S, Dorkoosh FA, Elsabee MZ. Chitosan nanoparticle to carry vitamin C through the gastrointestinal tract and induce the non-specific immunity system of rainbow trout (Oncorhynchus mykiss). Carbohydrate polymers. 2011 Aug 1;86(1):142-6. https://doi.org/10.1016/j.carbpol.2011.04.028

107. Ferosekhan S, Gupta S, R Singh A, Rather A, Kumari R, C Kothari D, Kumar Pal A, Balkrishna Jadhao S. RNA-loaded chitosan nanoparticles for enhanced growth, immunostimulation and disease resistance in fish. Current Nanoscience. 2014 Jun 1;10(3):453-64.

108. Ramos EA, Relucio JL, Torres-Villanueva CA. Gene expression in tilapia following oral delivery of chitosan-encapsulated plasmid DNA incorporated into fish feeds. Marine biotechnology. 2005 Apr;7(2):89-94. https://doi.org/10.1007/s10126-004-3018-0

109. Kumar SR, Ahmed VI, Parameswaran V, Sudhakaran R, Babu VS, Hameed AS. Potential use of chitosan nanoparticles for oral delivery of DNA vaccine in Asian sea bass (Lates calcarifer) to protect from Vibrio (Listonella) anguillarum. Fish \& Shellfish Immunology. 2008 Jul 1;25(1-2):47-56. https://doi.org/10.1016/j.fsi.2007.12.004

110. Kumar SR, Ahmed VI, Parameswaran V, Sudhakaran R, Babu VS, Hameed AS. Potential use of chitosan nanoparticles for oral delivery of DNA vaccine in Asian sea bass (Lates calcarifer) to protect from Vibrio (Listonella) anguillarum. Fish \& Shellfish Immunology. 2008 Jul 1;25(1-2):47-56. https://doi.org/10.1016/j.fsi.2007.12.004

111. Wang $Y$, Li J. Effects of chitosan nanoparticles on survival, growth and meat quality of tilapia, Oreochromis nilotica. Nanotoxicology. 2011 Sep 1;5(3):425-31. https://doi.org/10.3109/17435390.2010.530354

112. Abdel-Tawwab M, Shukry M, Farrag FA, El-Shafai NM, Dawood MA, Abdel-Latif HM. Dietary sodium butyrate nanoparticles enhanced growth, digestive enzyme activities, intestinal histomorphometry, and transcription of growth-related genes in Nile tilapia juveniles. $\begin{array}{llll}\text { Aquaculture. } & 2021 & \text { Apr } & 15 ; 536: 736467 .\end{array}$ https://doi.org/10.1016/j.aquaculture.2021.736467

113. Petrovič $\mathrm{V}$, Nollet $\mathrm{L}$, Kováč $\mathrm{G}$. Effect of dietary supplementation of trace elements on the growth performance and their distribution in the breast and thigh muscles depending on the age of broiler chickens. Acta Veterinaria Brno. 2010;79(2):203-9. https://doi.org/10.2754/avb201079020203

114. Li L, Lin SL, Deng L, Liu ZG. Potential use of chitosan nanoparticles for oral delivery of DNA vaccine in black seabream Acanthopagrus schlegelii Bleeker to protect from Vibrio parahaemolyticus. Journal

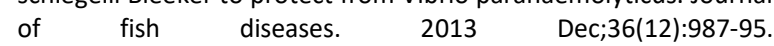
https://doi.org/10.1111/jfd.12032

115. Aranaz I, Mengíbar M, Harris R, Paños I, Miralles B, Acosta N, Galed $\mathrm{G}$, Heras Á. Functional characterization of chitin and chitosan. Current chemical biology. 2009 May 1;3(2):203-30. https://doi.org/10.2174/187231309788166415

116. Rajeshkumar S, Venkatesan C, Sarathi M, Sarathbabu V, Thomas J, Basha KA, Hameed AS. Oral delivery of DNA construct using chitosan nanoparticles to protect the shrimp from white spot syndrome virus (WSSV). Fish \& Shellfish Immunology. 2009 Mar 1;26(3):429-37. https://doi.org/10.1016/j.fsi.2009.01.003

117. Srinivasan V, Bhavan PS, Rajkumar G, Satgurunathan T, Muralisankar T. Dietary supplementation of magnesium oxide (MgO) nanoparticles for better survival and growth of the freshwater prawn Macrobrachium rosenbergii post-larvae. Biological trace element research. 2017 May 1;177(1):196-208. https://doi.org/10.1007/s12011-016-0855-4

118. Xu H, Zhang $X$, Wei $Y$, Sun B, Jia L, Liang M. Effects of dietary phosphorus level and stocking density on tiger puffer Takifugu rubripes: Growth performance, body composition, lipid metabolism, deposition of phosphorus and calcium, serum 
biochemical parameters, and phosphorus excretion. Aquaculture. 2020 Dec 15;529:735709. https://doi.org/10.1016/j.aquaculture.2020.735709

119. Manuel y Keenoy B, Moorkens G, Vertommen J, Noe M, Neve J, De Leeuw I. Magnesium status and parameters of the oxidantantioxidant balance in patients with chronic fatigue: effects of supplementation with magnesium. Journal of the American College of Nutrition. 2000 Jun 1;19(3):374-82. https://doi.org/10.1080/07315724.2000.10718934

120. Tang ZX, Lv BF. MgO nanoparticles as antibacterial agent: preparation and activity. Brazilian Journal of Chemical Engineering. 2014;31:591-601. 6632.20140313500002813

121. Ogino C. Requirements of carp and rainbow trout for essential amino acids. Bulletin of the Japanese Society of Scientific Fisheries. 1980.

122. Gatlin III DM, Wilson RP. Dietary zinc requirement of fingerling channel catfish. The Journal of nutrition. 1983 Mar 1;113(3):630-5 https://doi.org/10.1093/jn/113.3.630

123. Maage A, Lygren B, El-Mowafi AF. Manganese requirement of Atlantic salmon (Salmo salar) fry. Fisheries science. 2000;66(1):1-8. https://doi.org/10.1046/j.1444-2906.2000.00001.x

124. Tan XY, Xie $P$, Luo $Z$, Lin HZ, Zhao YH, Xi WQ. Dietary manganese requirement of juvenile yellow catfish Pelteobagrus fulvidraco, and effects on whole body mineral composition and hepatic intermediary metabolism. Aquaculture. 2012 Jan 25;326:68-73. https://doi.org/10.1016/j.aquaculture.2011.11.013

125. Ma R, Hou H, Mai K, Bharadwaj AS, Ji F, Zhang W. Comparative study on the effects of chelated or inorganic manganese in diets containing tricalcium phosphate and phytate on the growth performance and physiological responses of turbot Scophthalmus maximus. Aquaculture Nutrition. 2015 Dec;21(6):780-7. https://doi.org/10.1111/anu.12206

126. Lin YH, Lin SM, Shiau SY. Dietary manganese requirements of juvenile tilapia, Oreochromis niloticus O. aureus. Aquaculture. 2008 Nov https://doi.org/10.1016/j.aquaculture.2008.07.049 $1 ; 284(1-4): 207-10$

127. Pan L, Zhu X, Xie S, Lei W, Han D, Yang Y. Effects of dietary manganese on growth and tissue manganese concentrations of juvenile gibel carp, Carassius auratus gibelio. Aquaculture Nutrition. 2008 Oct;14(5):459-63. https://doi.org/10.1111/j.13652095.2007.00550.x

128. Ye Cx, Tian Lx, Yang Hj, Liang Jj, Niu J, Liu Yj. Growth performance and tissue mineral content of juvenile grouper (Epinephelus coioides) fed diets supplemented with various levels of manganese. Aquaculture Nutrition. $2009 \quad$ Dec;15(6):608-14. https://doi.org/10.1111/j.1365-2095.2008.00628.x

129. Wang $D$, Zhao L, Tan $Y$. Requirement of the fingerling grass carp (Ctenopharyngodon idellus) for choline. Journal of Fisheries of China. 1995;19(2):133-9.

130. Liu K, Ai QH, Mai KS, Zhang WB, Zhang L, Zheng SX. Dietary manganese requirement for juvenile cobia, $R$ achycentron canadum L. Aquaculture Nutrition. 2013 Aug;19(4):461-7. https://doi.org/10.1111/j.1365-2095.2012.00979.x

131. Kádár $\mathrm{E}$, Lowe $\mathrm{DM}$, Solé $\mathrm{M}$, Fisher $\mathrm{AS}$, Jha $\mathrm{AN}$, Readman JW, Hutchinson TH. Uptake and biological responses to nano-Fe versus soluble $\mathrm{FeCl} 3$ in excised mussel gills. Analytical and bioanalytical chemistry. $2010 \quad$ Jan;396(2):657-66. https://doi.org/10.1007/s00216-009-3191-0

132. Behera T, Swain P, Rangacharulu PV, Samanta M. Nano-Fe as feed additive improves the hematological and immunological parameters of fish, Labeo rohita H. Applied Nanoscience. 2014 Aug;4(6):687-94. https://doi.org/10.1007/s13204-013-0251-8

133. El-Shenawy AM, Gad DM, Yassin SA. Effect of Iron Nanoparticles on the Development of Fish Farm Feeds. Alexandria Journal for Veterinary Sciences. 2019 Jan 1;60(1). DOI: 10.5455/ajvs.28123

134. Dirba I, Schwöbel CA, Zintler A, Komissinskiy P, Molina-Luna L, Gutfleisch O. Production of Fe nanoparticles from $y$-Fe 203 by high-pressure hydrogen reduction. Nanoscale Advances. 2020;2(10):4777-84. DOI: 10.1039/DONA00635A

135. Hilty FM, Arnold M, Hilbe M, Teleki A, Knijnenburg JT, Ehrensperger $F$, Hurrell RF, Pratsinis SE, Langhans W, Zimmermann MB. Iron from nanocompounds containing iron and zinc is highly bioavailable in rats without tissue accumulation. Nature nanotechnology. 2010 May;5(5):374-80. https://doi.org/10.1038/nnano.2010.79

136. Srinivasan V, Bhavan PS, Rajkumar G, Satgurunathan T, Muralisankar T. Effects of dietary iron oxide nanoparticles on the growth performance, biochemical constituents and physiological stress responses of the giant freshwater prawn Macrobrachium rosenbergii post-larvae. International Journal of Fisheries and Aquatic Studies. 2016;4(2):170-82.

137. Rather MA, Sharma R, Aklakur M, Ahmad S, Kumar N, Khan M, Ramya VL. Nanotechnology: a novel tool for aquaculture and fisheries development. A prospective mini-review. Fisheries and Aquaculture Journal. 2011;16(1-5):3.

138. Akter N, Alam MJ, Jewel MA, Ayenuddin M, Haque SK, Akter S. Evaluation of dietary metallic iron nanoparticles as feed additive for growth and physiology of Bagridae catfish Clarias batrachus (Linnaeus, 1758). International Journal of Fisheries and Aquatic Studies. 2018;6(3):371-7.

139. Wang $M Q, X u Z R$, Zha LY, Lindemann MD. Effects of chromium nanocomposite supplementation on blood metabolites, endocrine parameters and immune traits in finishing pigs. Animal Feed Science and Technology. 2007 Dec 3;139(1-2):69-80. https://doi.org/10.1016/i.anifeedsci.2006.12.004

140. Wang MQ, Xu ZR. Effect of chromium nanoparticle on growth performance, carcass characteristics, pork quality and tissue chromium in finishing pigs. Asian-Australasian Journal of Animal Sciences. https://doi.org/10.5713/ajas.2004.1118

141. Ahmad N, Hussain SM, Ali Q, Jabeen F, Asrar M, Shahzad MM Arsalan MZ. Effects of chromium nanoparticles supplementation on body composition of Cirrhinus mrigala fingerlings fed sunflower meal based diet. http://dx.doi.org/10.17582/journal.pjz/2019.51.5.1943.1952

142. Hussain SM, Nisar A, Rasul A, Shahzad MM, Latif M, Arsalan MZ, Umair M, Shafqat HH. Efficacy of nano-Cr particles supplemented sunflower meal based diets on growth performance, digestibility and hematology of Catla catla fingerlings. Pakistan Journal of Zoology. $2019 \quad$ Oct 31;51(5):1943. DOI: http://dx.doi.org/10.17582/journal.pjz/2019.51.5.1943.1952.

Source of Support: The author(s) received no financial support for the research, authorship, and/or publication of this article.

Conflict of Interest: The author(s) declared no potential conflicts of interest with respect to the research, authorship, and/or publication of this article. 